\title{
Synthesis and characterization of a novel schiff base metal complexes and their application in determination of iron in different types of natural water
}

\author{
Mostafa M. H. Khalil ${ }^{1 *}$, Eman H. Ismail ${ }^{1}$, Gehad G. Mohamed ${ }^{2}$, Ehab M. Zayed ${ }^{2}$, Ahmed Badr ${ }^{1}$ \\ ${ }^{1}$ Chemistry Department, Faculty of Science, Ain Shams University, Cairo, Egypt \\ ${ }^{2}$ Chemistry Department, Faculty of Science, Cairo University, Cairo, Egypt \\ Email: ${ }^{*}$ khalil62@yahoo.com
}

Received 23 October 2011; revised 20 January 2012; accepted 2 February 2012

\begin{abstract}
A novel and simple approach to the synthesis of macrocyclic Schiff base ligand resulted from the condensation of bisaldehyde and ethylenediamine was prepared $(7,8,15,16,17,18$-hexahydrodibenzo (a, g) (14) annulene) (L) and its complexes were synthesized and characterized using different physicochemical studies as elemental analysis, FT-IR, ${ }^{1} \mathrm{H}$ NMR, conductivity, magnetic properties, thermal analysis, and their biological activities. The spectroscopic data of the complexes suggest their 1:1 complexe structures which are investigated by elemental analysis, FT-IR, ${ }^{1} \mathrm{H}$ NMR, conductivity, magnetic properties, thermal analysis, and their biological activities. The spectroscopic studies suggested the octahedral structure for the all complexes. The spectroscopic data of the complexes suggest their structure in which $\left(\mathrm{N}_{2} \mathrm{O}_{2}\right)$ group act as a tetradentate ligand and two chlorides as monodentate ligands. Also electronic spectra and magnetic susceptibility measurements indicate octahedral structure of these complexes. The synthesized Schiff base and its metal complexes also were screened for their antibacterial and antifungal activity. Here we report the effect of a neutral chelating ligand on the complexation with iron to determine it in different types of natural water using recovery test. The activity data show that the metal complexes to be more potent/ antibacterial than the parent Schiff base ligand against one or more bacterial species.
\end{abstract}

Keywords: Novel Schiff Base; Transition Metal Complexes and Natural Water

\section{INTRODUCTION}

A large number of Schiff bases and their complexes have

"Corresponding author. been investigated for their interesting and important properties, such as their ability to reversibly bind oxygen [1], catalytic activity in the hydrogenation of olefines [2], photochromic properties [3,4] and complexing ability towards some toxic metals [5]. Schiff bases are a special class of ligands with a variety of donor atoms exhibiting interesting coordination modes towards various metals [68]. The azomethine linkage in Schiff bases is responsible for the biological activities such as antitumor, antibacterial, antifungal and herbicidal activities [9]. Designing a suitable polydentate Schiff base ligand to combine with a metal ion along with pseudohalide anion has opened a new area of synthesizing metal complexes of particular choice [10]. Such complexes are readily assembled from diamines and various salicylaldehyde derivatives and are amenable to combinatorial syntheses [11]. Metal Schiff base complexes have been well known for their easy synthesis, stability and wide application [12-14]. A large number of Schiff base $\left(\mathrm{N}_{2} \mathrm{O}_{2}\right)$ complexes have been reported so far, and their catalytic and biological properties have been studied intensively [15-21]. Numerous techniques were available in iron determination have been reported [22-24]. However, these techniques were tedious need time and rigid conditions. Also due to the very low concentrations of iron, lead and chromium in natural water samples, their determinations demand very sensitive analytical techniques including ET-AAS, ICP-MS, ICPAES and XRF. However, relative to flame AAS, these techniques have some disadvantages such as its high cost, slowness and greater proneness to matrix interferences as well as their high sensitive advantages [25]. The present study was under taken to throw more light on the chelation behavior of Schiff base (L) towards some transition elements, which may help in more understanding of the mode of chelation of the new Schiff base towards metals and tried to used in the recovery test with a purity of more than higher than $96 \%$ for the metal ion. 


\section{EXPERIMENTAL}

\subsection{Materials and Solutions}

The chemicals used included metal (II) and (III) chlorides. Solvents of absolute ethyl alcohol, diethylether, dimethylformamide and ethylenediamine were spectroscopic pure and purchased from $\mathrm{BDH}$. A $10^{-4} \mathrm{M}$ solution of the metal salts $\left(\mathrm{CrCl}_{3} \cdot 6 \mathrm{H}_{2} \mathrm{O}(0.341 \mathrm{~g} / \mathrm{L}), \mathrm{CoCl}_{2} \cdot 6 \mathrm{H}_{2} \mathrm{O}(0.119\right.$ $\mathrm{g} / \mathrm{L}), \mathrm{NiCl}_{2} \cdot 6 \mathrm{H}_{2} \mathrm{O}(0.119 \mathrm{~g} / \mathrm{L})(\mathrm{BDH}), \mathrm{FeCl}_{3} \cdot 6 \mathrm{H}_{2} \mathrm{O}(0.117$ $\mathrm{g} / \mathrm{L}$ ) (Prolabo), $\mathrm{CuCl}_{2} \cdot 2 \mathrm{H}_{2} \mathrm{O}(0.085 \mathrm{~g} / \mathrm{L}$ ) (Sigma) and $\mathrm{ZnCl}_{2} \cdot 2 \mathrm{H}_{2} \mathrm{O}(0.086 \mathrm{~g} / \mathrm{L})$ (Ubichem)) were prepared by dissolving the accurately weighed amounts of the metal salts in the appropriate volume of de-ionized water. The metal salt solutions were standardized by the recommended procedures [26].

\subsection{Instrumentation}

Elemental microanalyses of the separated solid chelates for $\mathrm{C}, \mathrm{H}, \mathrm{N}$ and $\mathrm{Cl}$ were performed at the Microanalytical center, Cairo University. The molar conductance of the complexes in DMF was measured using Sybron-Barnstead conductometer (Meter-PM.6, E = 3406). Infrared spectra were recorded on a Perkin-Elmer FT-IR type 1650 spectrophotometer. The spectra were recorded as $\mathrm{KBr}$ pellets. The UV-vis absorption spectra were measured on a Shimadzu 3101pc spectrophotometer. The molar magnetic susceptibility was measured on powdered samples using the Faraday method. The diamagnetic corrections were made by Pascal's constant and $\mathrm{Hg}\left[\mathrm{Co}(\mathrm{SCN})_{4}\right]$ was used as a calibrant. The mass spectra were recorded by the EI technique at $70 \mathrm{eV}$ using MS5988 GS-MS Hewlett-Packard instrument. The ${ }^{\text {HINMR }}$ spectra were recorded using $300 \mathrm{MHz}$ Varian-Oxford Mercury. The thermal analyses were carried out in dynamic nitrogen atmosphere $\left(20 \mathrm{~mL} \cdot \mathrm{min}^{-1}\right)$ with a heating rate of $10^{\circ} \mathrm{C} \cdot \mathrm{min}^{-1}$ using Shimadzu TG-60H thermal analyzer. XPD analyses were carried out by using Philips Analytical X-Ray BV, diffractometer type PW 1840. Radiation was provided by copper target (Cu anode $2000 \mathrm{~W}$ ) high intensity X-ray tube operated at $40 \mathrm{KV}$ and $25 \mathrm{~mA}$. All spectrophotometric measurements were preformed using a Unicam UV-2 spectrophotometer using $10 \mathrm{~mm}$ quartz cell and a blank solution as a reference. The $\mathrm{pH}$ measurements were made using HANNA $\mathrm{pH}$ meter.

\subsection{Synthesis of the Compounds}

\subsubsection{Synthesis of Bisaldehyde}

Salicylaldehyde $(20 \mathrm{mmol})$ was dissolved in hot ethanolic $\mathrm{KOH}$ (prepared by dissolving $1.12 \mathrm{~g}(20 \mathrm{mmol})$ of $\mathrm{KOH}$ in $20 \mathrm{ml}$ of absolute ethanol), and the solvent was then removed in vacuo. The remaining material was dissolved in DMF (15 ml) and the appropriate 1,2-dibromoethane $(10 \mathrm{mmol})$ was added. The reaction mixture was refluxed for 5 min during which $\mathrm{KCl}$ was separated. The solvent was then removed in vacuo and the remaining materials was washed with water and purified by crystallization.

\subsubsection{Synthesis of Schiff Base}

Hot solution $\left(60^{\circ} \mathrm{C}\right)$ of ethylenediamine $(0.399 \mathrm{~g}, 6.67$ $\mathrm{mmol}$ ) in $50 \mathrm{~mL}$ ethanol/DMF mixture as $1: 1$ mole ratio mixed with hot solution $\left(60^{\circ} \mathrm{C}\right)$ of bisaldehyde $(1.6 \mathrm{~g}$, $6.67 \mathrm{mmol}$ ) in the same solvent and the reaction mixture was left under heating for $30 \mathrm{~min}$. A solid mass separated was collected and washed with diethylether. Crystallization was done with ethanol and then dried over $\mathrm{CaCl}_{2}$. The pale yellow ligand; L, (yield, $82 \%$ ) was collected.

\subsubsection{Synthesis of Metal Complexes}

All the new complexes were prepared by adding hot ethanolic/DMF solution in a $1: 1$ molar ratio $\left(60^{\circ} \mathrm{C}\right)$ of metal (II)/(III) $(1 \mathrm{mmol})$ to hot solution $\left(60^{\circ} \mathrm{C}\right)$ of ligand in the same solvent. The solution was stirred with heating for one hour whereupon the complexes precipitated then filtered and left for drying. A solid residue was separated and washed by diethylether. Crystallization was done with methanol and the complexes dried over anhydrous $\mathrm{CaCl}_{2}$ and the metal contents were determined compleximetrically.

\subsection{Biological Activity}

The standard disc-agar diffusion method [27] was followed to determine the antibacterial and antifungal activeity of the synthesized compounds. The tested compounds were dissolved in DMF (which have no inhibittion activity), to get concentrations of $100 \mu \mathrm{g} / \mathrm{mL}$. Uniform size filter paper disks (3 disks per compound) were impregnated by equal volume $(0.1 \mathrm{~mL})$ from the specific concentration of dissolved tested compounds and carefully placed on incubated agar surface. After incubation for $48 \mathrm{~h}$ at $37^{\circ} \mathrm{C}$, inhibition of the organisms which evidenced by clear zone surround each disk was measured and used to calculate mean of inhibition zones.

\subsection{The Recovery Procedure}

Water samples were collected according to the recommended standard methods [28]. Water samples were spiked with a definite concentration of Fe(III) soluation and $1 \mathrm{ml}$ of $10^{-4} \mathrm{M}$ of the Schiff base was added. After adjusting the $\mathrm{pH}$ with $\mathrm{HNO}_{3}$ and/or $\mathrm{NaOH}$, the solution was shaked well and transferred to the measurement cell to ensure complete complexation. The concentration of metal ion determined spectrophotometrically and obtained the recovery percentage.

\section{RESULTS AND DISCUSSION}

The results of elemental analyses of the ligand and its 
complexes are in good agreement with those required by the proposed formulae giving in Table 1. The molecular modeling of Schiff base ligand (using Chem3D ultra 8.0 program) shows that the bond lengths of all bonds in the left and right hand sides are typical due to the similarity of moieties on the two sides. Mass spectrum (Figure 1) of the new Schiff base showed a signal with $\mathrm{m} / \mathrm{z}=301$ which is close to the calculated formula $\mathrm{m} / \mathrm{z}=294$, supporting the structures of the Schiff base. The fragments observed were in good agreement with the proposed formula (Scheme 1).

\subsection{Molar Conductance Measurements}

The metal (II)/(III) complexes were dissolved in DMSO and the molar conductivities of $10^{-3} \mathrm{M}$ of their solutions were measured at room temperature. The conductance values of the M(III) complexes support their electrolytic nature (1:1) types while $\mathrm{M}(\mathrm{II})$ complexes are non ionic in nature and non electrolytes. The data are listed in Table $\mathbf{1 .}$

\subsection{IR Spectral Studies}

IR spectra in the region $4000-400 \mathrm{~cm}^{-1}$ have been recorded for the ligand and its complexes and the assignments of the observed frequencies have been made to specific group vibrations by comparison with the spectra of related complexes. The IR spectrum of the ligand showed a shoulder at $1597 \mathrm{~cm}^{-1}$ assigned to $v(\mathrm{C}=\mathrm{N})$ of the azomethine stretching vibration, beside a band at $1049 \mathrm{~cm}^{-1}$ due to $\mathrm{C}-\mathrm{O}-\mathrm{C}$ stretching frequency. These two bands are shifted to higher or lower wave numbers in the complexes indicating the participation of the azomethine nitrogen in coordination [29] and the oxygen of the ether group, Table 2. On the other hand, the IR spectra of the complexes exhibited new non-ligand bands in the range $432-467 \mathrm{~cm}^{-1}$ and in the range $492-594 \mathrm{~cm}^{-1}$ assigned as $\mathrm{M}-\mathrm{O}$ and $\mathrm{M}-\mathrm{N}$ stretching vibrations, respectively. Therefore, it can be concluded that (L) ligand binds to the metal ions through azomethine $\mathrm{N}$ and the ether $\mathrm{O}$ and the ligand behaves as neutral tetradentate ligand.

Table 1. Analytical and physical data of L ligand and its metal complexes.

\begin{tabular}{|c|c|c|c|c|c|c|c|c|c|}
\hline \multirow{2}{*}{ Compound } & \multirow{2}{*}{$\begin{array}{l}\text { Colour } \\
\text { (\%yield) }\end{array}$} & \multirow{2}{*}{$\begin{array}{l}\text { M.P. } \\
\left({ }^{\circ} \mathrm{C}\right)\end{array}$} & \multicolumn{5}{|c|}{$\%$ Found (calcd.) } & \multirow{2}{*}{$\begin{array}{l}\mu_{\text {eff. }} \\
\text { (B.M) }\end{array}$} & \multirow{2}{*}{$\Omega^{-1} \cdot \underset{2}{\Lambda_{\mathrm{m}}}{ }^{-1} \cdot \mathrm{cm}$} \\
\hline & & & $\mathrm{C}$ & $\mathrm{H}$ & $\mathrm{N}$ & M & $\mathrm{Cl}$ & & \\
\hline $\mathrm{L}=\left(\mathrm{C}_{18} \mathrm{H}_{18} \mathrm{~N}_{2} \mathrm{O}_{2}\right)$ & $\begin{array}{c}\text { Pale Yellow } \\
(82)\end{array}$ & 154 & $\begin{array}{c}73.75 \\
(73.47)\end{array}$ & $\begin{array}{c}6.02 \\
(6.12)\end{array}$ & $\begin{array}{c}9.82 \\
(9.52)\end{array}$ & ---- & ---- & ----- & ----- \\
\hline$\left[\mathrm{Cr}(\mathrm{L}) \mathrm{Cl}_{2}\right] \mathrm{Cl}$ & $\begin{array}{c}\text { Pale Yellow } \\
\text { (88) }\end{array}$ & 122 & $\begin{array}{c}47.91 \\
(47.75)\end{array}$ & $\begin{array}{c}3.41 \\
(3.98)\end{array}$ & $\begin{array}{c}6.57 \\
(6.19)\end{array}$ & $\begin{array}{c}11.65 \\
(11.47)\end{array}$ & $\begin{array}{l}23.48 \\
(23.54)\end{array}$ & 3.64 & 103.9 \\
\hline$\left[\mathrm{Fe}(\mathrm{L}) \mathrm{Cl}_{2}\right] \mathrm{Cl}$ & $\begin{array}{l}\text { Brown } \\
(77)\end{array}$ & 148 & $\begin{array}{l}47.16 \\
(47.34)\end{array}$ & $\begin{array}{c}3.76 \\
(3.94)\end{array}$ & $\begin{array}{c}6.49 \\
(6.14)\end{array}$ & $\begin{array}{c}12.58 \\
(12.22)\end{array}$ & $\begin{array}{c}23.39 \\
(23.34)\end{array}$ & 5.44 & 104.5 \\
\hline$\left[\mathrm{Co}(\mathrm{L}) \mathrm{Cl}_{2}\right]$ & $\begin{array}{l}\text { Green } \\
(83)\end{array}$ & 114 & $\begin{array}{c}50.51 \\
(50.96)\end{array}$ & $\begin{array}{c}4.45 \\
(4.25)\end{array}$ & $\begin{array}{c}6.25 \\
(6.60)\end{array}$ & $\begin{array}{c}13.42 \\
(13.89)\end{array}$ & $\begin{array}{l}16.48 \\
(16.75)\end{array}$ & 4.49 & 32.51 \\
\hline$\left[\mathrm{Ni}(\mathrm{L}) \mathrm{Cl}_{2}\right]$ & $\begin{array}{c}\text { Yellowish Green } \\
\text { (89) }\end{array}$ & 120 & $\begin{array}{c}50.96 \\
(50.98)\end{array}$ & $\begin{array}{c}4.31 \\
(4.25)\end{array}$ & $\begin{array}{c}6.88 \\
(6.61)\end{array}$ & $\begin{array}{l}13.50 \\
(13.85)\end{array}$ & $\begin{array}{c}16.49 \\
(16.76)\end{array}$ & 3.21 & 31.25 \\
\hline$\left[\mathrm{Cu}(\mathrm{L}) \mathrm{Cl}_{2}\right]$ & $\begin{array}{l}\text { Green } \\
(74)\end{array}$ & 130 & $\begin{array}{c}50.74 \\
(50.41)\end{array}$ & $\begin{array}{c}4.90 \\
(4.20)\end{array}$ & $\begin{array}{c}6.84 \\
(6.53)\end{array}$ & $\begin{array}{c}14.63 \\
(14.82)\end{array}$ & $\begin{array}{c}16.66 \\
(16.57)\end{array}$ & 1.99 & 35.14 \\
\hline$\left[\mathrm{Zn}(\mathrm{L}) \mathrm{Cl}_{2}\right]$ & $\begin{array}{c}\text { Pale Yellow } \\
(81)\end{array}$ & 260 & $\begin{array}{c}50.34 \\
(50.19) \\
\end{array}$ & $\begin{array}{c}4.52 \\
(4.18) \\
\end{array}$ & $\begin{array}{c}6.08 \\
(6.51) \\
\end{array}$ & $\begin{array}{c}15.04 \\
(15.19) \\
\end{array}$ & $\begin{array}{c}16.79 \\
(16.50) \\
\end{array}$ & ---- & 17.92 \\
\hline
\end{tabular}
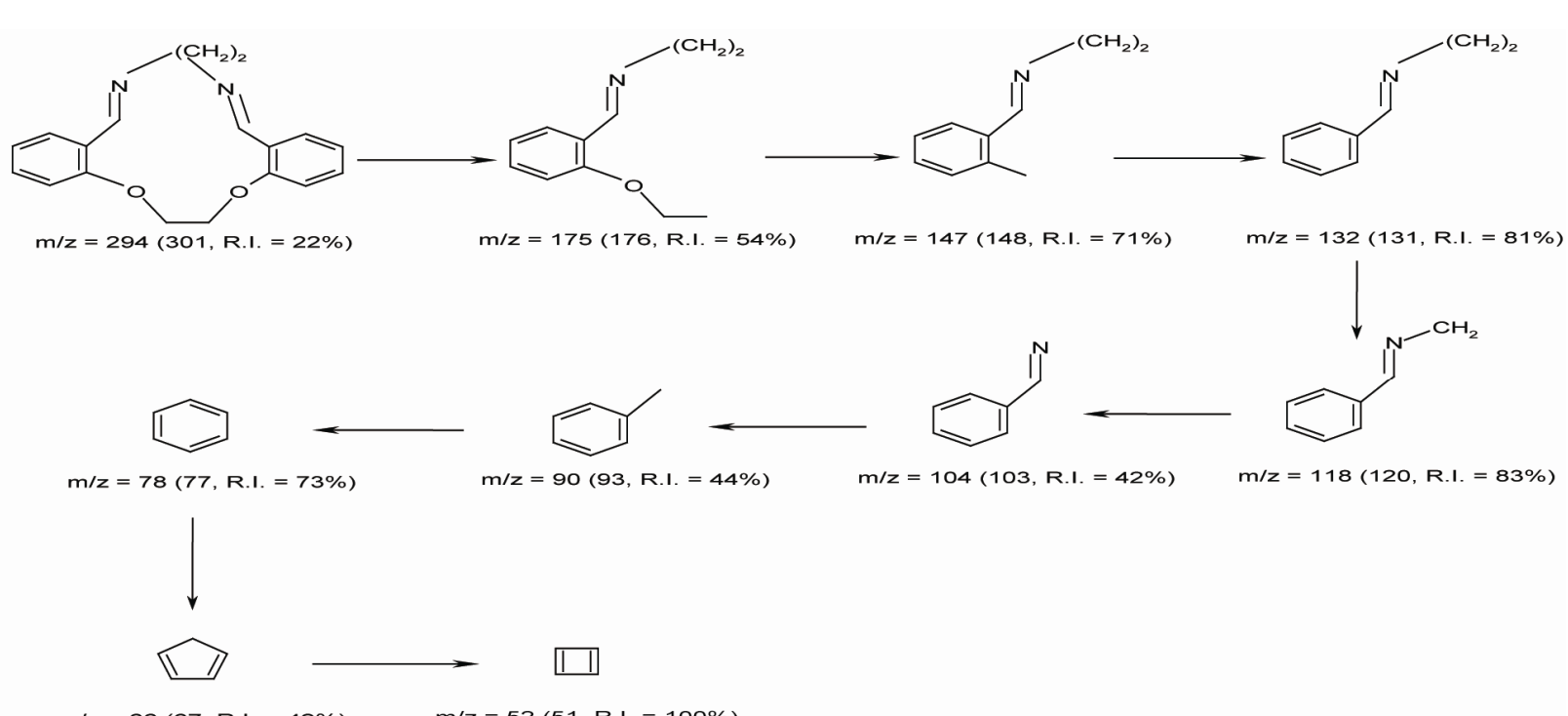

Scheme 1. Mass fragmentation pattern of L ligand. 


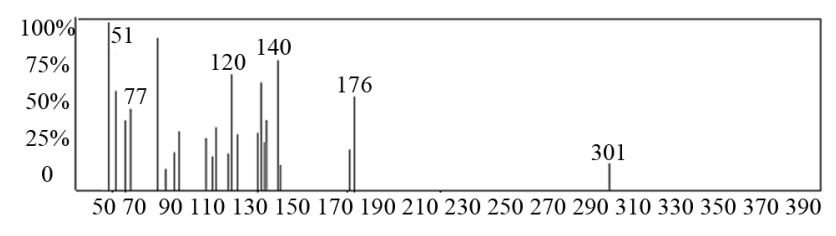

Figure 1. Mass spectra of Schiff base ligand (L).

Table 2. IR data $\left(4000-400 \mathrm{~cm}^{-1}\right)$ of L ligand and its metal complexes.

\begin{tabular}{ccccc}
\hline Compound & $v(\mathrm{HC}=\mathrm{N})_{\text {azomethine }}$ & $(\mathrm{C}-\mathrm{O}-\mathrm{C})_{\text {ether }}$ & $v(\mathrm{M}-\mathrm{N})_{\text {azo }}$ & $v(\mathrm{M}-\mathrm{O})_{\text {ether }}$ \\
\hline $\mathrm{L}$ & $1597 \mathrm{sh}$ & $1049 \mathrm{sh}$ & ------ & ----- \\
{$\left[\mathrm{Cr}(\mathrm{L}) \mathrm{Cl}_{2}\right] \mathrm{Cl}$} & $1611 \mathrm{sh}$ & $1061 \mathrm{sh}$ & $502 \mathrm{~s}$ & $440 \mathrm{~s}$ \\
{$\left[\mathrm{Fe}(\mathrm{L}) \mathrm{Cl}_{2}\right] \mathrm{Cl}$} & $1590 \mathrm{sh}$ & $1038 \mathrm{sh}$ & $498 \mathrm{~m}$ & $464 \mathrm{~m}$ \\
{$\left[\mathrm{Co}(\mathrm{L}) \mathrm{Cl}_{2}\right]$} & $1593 \mathrm{~m}$ & $1057 \mathrm{sh}$ & $505 \mathrm{w}$ & $432 \mathrm{~s}$ \\
{$\left[\mathrm{Ni}(\mathrm{L}) \mathrm{Cl}_{2}\right]$} & $1600 \mathrm{sh}$ & $1038 \mathrm{~m}$ & $521 \mathrm{~s}$ & $436 \mathrm{~s}$ \\
{$\left[\mathrm{Cu}(\mathrm{L}) \mathrm{Cl}_{2}\right]$} & $1589 \mathrm{sh}$ & $1053 \mathrm{~m}$ & $502 \mathrm{w}$ & $436 \mathrm{~m}$ \\
{$\left[\mathrm{Zn}(\mathrm{L}) \mathrm{Cl}_{2}\right]$} & $1601 \mathrm{~m}$ & $1049 \mathrm{~m}$ & $594 \mathrm{w}$ & $467 \mathrm{~s}$ \\
\hline
\end{tabular}

$\mathrm{Sh}=$ sharp $; \mathrm{m}=$ medium $; \mathrm{br}=$ broad $; \mathrm{s}=$ small $; \mathrm{w}=$ week .

\section{3. $\mathrm{H}^{1} \mathrm{NMR}$ Spectra}

The $\mathrm{H}^{1} \mathrm{NMR}$ spectra of Schiff base ligand (L) is recorded in $\mathrm{d}_{6}$-dimethylsulfoxide (DMSO) solution using tetramethylsilane (TMS) as internal standard. The chemical shifts of the different types of protons found in the ${ }^{\text {H1NMR }}$ spectra of the Schiff base ligand is compared with its diamagnetic $\mathrm{Zn}$ (II) complex and shown in Table 3. It is found that while the ${ }^{\mathrm{H}_{\mathrm{NNMR}}}$ signal of $(\mathrm{HC}=\mathrm{N})$ is shifted due to complexation, the signals due to the ether $\mathrm{CH}_{2}-\mathrm{O}$ does not show a significant shift in the chelation mode.

\subsection{Electronic Absorption Spectra and Magnetic Moments of the Metal Complexes}

The Uv-vis spectrum of the ligand showed two bands at 330 and $370 \mathrm{~nm}$ which are assigned to $\pi-\pi^{*}$ and $n-\pi^{*}$, transition, respectively. The Uv-vis spectra of $10^{-4} \mathrm{M}$ of the metal complexes, Figure 2, display similar absorption spectra of the ligand which are shifted to lower and higher wavelengths beside a decrease or disappearance of the peak dye to $n-\pi^{*}$ transition which confirm the coordination through azomethine nitrogen. On the other hand, $\pi-\pi^{*}$ transition showed shoulder at $337 \mathrm{~nm}$ with new band at $320 \mathrm{~nm}$ due to complexation. Also the d-d transition in this type of complexes may appear above $500 \mathrm{~nm}$ but does not appear due to the low intensity of the d-d transition. The data listed in Table 1 summarized the measured magnetic moment values. These data support the octahedral geometry of the complexes.

Table 3. ${ }^{\text {HINMR }}$ spectral data of the organic ligand and its metal chelates.

\begin{tabular}{ccc}
\hline Compound & Chemical shift, $(\delta) \mathrm{ppm}$ & Assignment \\
\hline $\mathrm{L}$ & 4.434 & $\left(\mathrm{~m}, 2 \mathrm{H},-\mathrm{OCH}_{2}\right)$ \\
& $2.725-2.888$ & $\left(\mathrm{~m}, 2 \mathrm{H},-\mathrm{C}=\mathrm{N}-\mathrm{CH}_{2}\right)$ \\
$6.885-7.950$ & $(\mathrm{~m}, 4 \mathrm{H}, \mathrm{ArH})$ \\
& $8.479-8.493$ & $(\mathrm{~m}, 1 \mathrm{H}$, azomethineH $)$ \\
& 4.435 & $\left(\mathrm{~m}, 2 \mathrm{H},-\mathrm{OCH}_{2}\right)$ \\
{$\left[\mathrm{Zn}(\mathrm{L}) \mathrm{Cl}_{2}\right]$} & $2.729-2.887$ & $\left(\mathrm{~m}, 2 \mathrm{H},-\mathrm{C}=\mathrm{N}-\mathrm{CH}_{2}\right)$ \\
& $6.943-7.821$ & $(\mathrm{~m}, 4 \mathrm{H}, \mathrm{ArH})$ \\
& 8.546 & $(\mathrm{~s}, 1 \mathrm{H}$, azomethineH $)$ \\
\hline
\end{tabular}

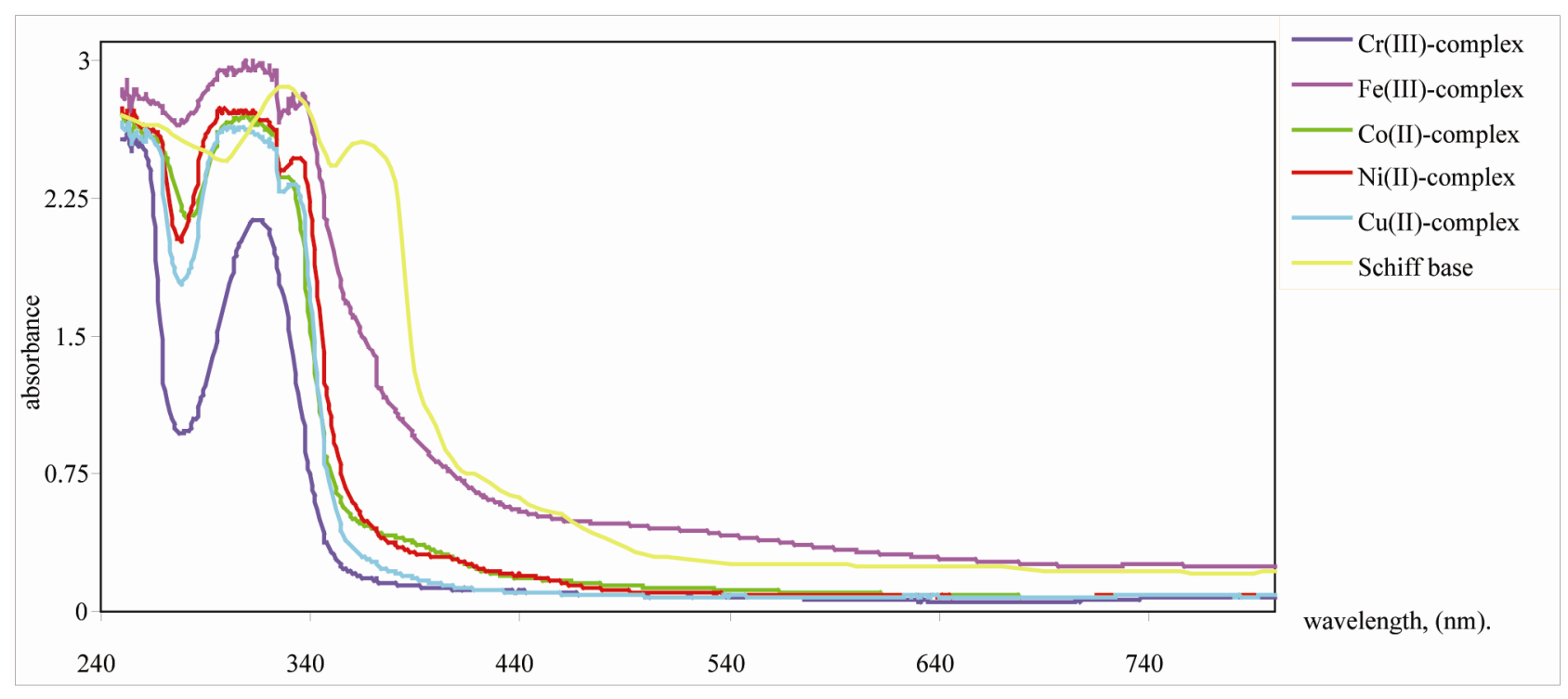

Figure 2. Uv-vis spectrum of the Schiff base and its metal complexes. 


\subsection{Thermal Analyses (TG and DTG) Studies}

The Schiff base ligand exhibits a first estimated mass loss of $13.33 \%$ (calcd. $12.93 \%$ ) at $25^{\circ} \mathrm{C}-140^{\circ} \mathrm{C}$, which may be attributed to the liberation of $2 \mathrm{NH}_{3}$ and $2 \mathrm{H}_{2}$ molecules as gases. In the following stages within the temperature range from $140^{\circ} \mathrm{C}-750^{\circ} \mathrm{C}$, the organic part $\mathrm{C}_{17} \mathrm{H}_{8}$ with $\mathrm{CO}_{2}$ gas are lost with an estimated mass loss of $86.67 \%$ (calcd. $87.07 \%$ ). The thermogram of Fe(III)-L chelate show three decomposition steps within the temperature range from $50^{\circ} \mathrm{C}-790^{\circ} \mathrm{C}$. The first step of decomposition within the temperature range from $50^{\circ} \mathrm{C}$ $245^{\circ} \mathrm{C}$ corresponds to the loss of $2 \mathrm{HCl}$ gases with an estimated mass loss of $16.18 \%$ (calcd. 16.00\%). While the second step occurs within the temperature range from $245^{\circ} \mathrm{C}-520^{\circ} \mathrm{C}$ and corresponds to the removal of $\mathrm{HCl}$,
$\mathrm{CO}$ and $2 \mathrm{NH}_{3}$ as gases with a mass loss of $21.91 \%$ (calcd. $21.58 \%)$. The final step $\left(520^{\circ} \mathrm{C}-790^{\circ} \mathrm{C}\right)$ corresponds to the removal of the organic part of the ligand leaving metal oxide as a residue. The overall weight loss amounts to $84.37 \%$ (calcd. $84.27 \%$ ). The TG curve of the cobalt complex shows five stages of decomposition within the temperature range of $25^{\circ} \mathrm{C}-705^{\circ} \mathrm{C}$. The first three stages at $25^{\circ} \mathrm{C}-270^{\circ} \mathrm{C}$ correspond to the loss of $2 \mathrm{HCl}$ as gases in the first step and $\mathrm{NO}$ and $\mathrm{NH}_{3}$ as gases in the next steps, while the final stages involve the loss of organic molecule leaving the metal oxide as residue. The overall weight loss amounts to $82.90 \%$ (calcd. 82.33\%). The $\mathrm{Cu}$ (II) complex decomposed in four steps. The overall weight loss amounts to $82.22 \%$ (calcd. $81.45 \%$ ), Table 4 and Figure 3.

Table 4. Thermoanalytical results of Schiff base and its metal complexes.

\begin{tabular}{|c|c|c|c|c|c|c|c|}
\hline \multirow{2}{*}{$\frac{\text { Compound }}{\mathrm{L}}$} & \multirow[t]{2}{*}{$\begin{array}{l}\text { TG Range } \\
\left({ }^{\circ} \mathrm{C}\right)\end{array}$} & \multirow{2}{*}{$\begin{array}{c}\mathrm{DTG}_{\max } \\
\left({ }^{\circ} \mathrm{C}\right)\end{array}$} & \multirow[t]{2}{*}{$\mathrm{n}^{*}$} & \multicolumn{2}{|c|}{$\begin{array}{l}\text { Mass Loss Total Mass Loss Calcd } \\
\text { (Estim) } \%\end{array}$} & \multirow[t]{2}{*}{ Assignment } & \multirow[t]{2}{*}{$\begin{array}{l}\text { Metallic } \\
\text { Residue }\end{array}$} \\
\hline & & & & & & & \\
\hline \multirow{4}{*}[\mathrm{Fe}(\mathrm{L})\mathrm{Cl}_{2}]{$\mathrm{Cl}$} & $25-140$ & 318,399 & 1 & $12.93(13.33)$ & & -Loss of $2 \mathrm{NH}_{3}$ and $2 \mathrm{H}_{2}$ & \multirow[t]{2}{*}{------ } \\
\hline & $140-750$ & 501,612 & 4 & $87.07(86.67)$ & $100(100)$ & -Loss of $\mathrm{CO}_{2}$ and $\mathrm{C}_{17} \mathrm{H}_{8}$ & \\
\hline & $50-245$ & 187 & 1 & $16.00(16.18)$ & & - Loss of $2 \mathrm{HCl}$ & $\mathrm{FeO}$ \\
\hline & $245-520$ & 384 & 1 & $21.59(21.91)$ & & -Loss of $\mathrm{HCl}, \mathrm{CO}$ and $2 \mathrm{NH}_{3}$ & 15.74 \\
\hline \multirow[t]{3}{*}[\mathrm{Co}(\mathrm{L})\mathrm{Cl}_{2}]{} & $25-270$ & 30,205 & 2 & $17.22(17.03)$ & & - Loss of $2 \mathrm{HCl}$ & $\mathrm{CoO}$ \\
\hline & $270-415$ & 362 & 1 & $11.09(11.58)$ & & -Loss of $\mathrm{NO}$ and $\mathrm{NH}_{3}$ & 17.67 \\
\hline & $415-705$ & 625,937 & 2 & $54.02(54.29)$ & $82.33(82.90)$ & -Loss of $\mathrm{C}_{18} \mathrm{H}_{13}$ & $(17.10)$ \\
\hline \multirow[t]{3}{*}[\mathrm{Cu}(\mathrm{L})\mathrm{Cl}_{2}]{} & & & & & & - Loss of $2 \mathrm{HCl}$ & $\mathrm{CuO}$ \\
\hline & $35-220$ & 125,229 & 2 & $17.04(17.84)$ & & -Loss of $2 \mathrm{NH}_{3}, 1 / 2 \mathrm{O}_{2}$ and & 18.55 \\
\hline & $220-775$ & 345,593 & 2 & $64.41(64.38)$ & $81.45(82.22)$ & $\mathrm{C}_{18} \mathrm{H}_{10}$ & $(17.78)$ \\
\hline
\end{tabular}

$\mathrm{n}^{*}=$ number of decomposition steps.

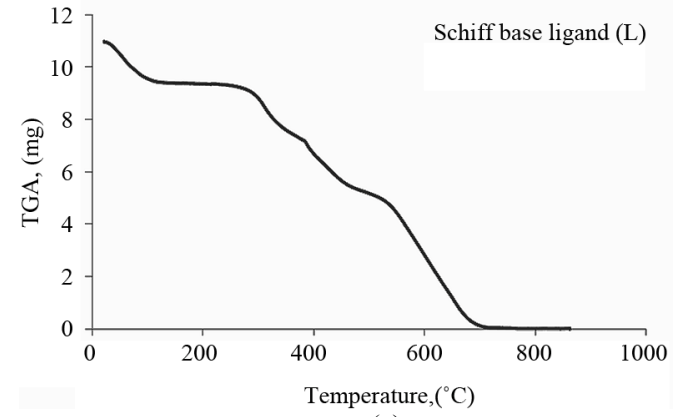

(a)

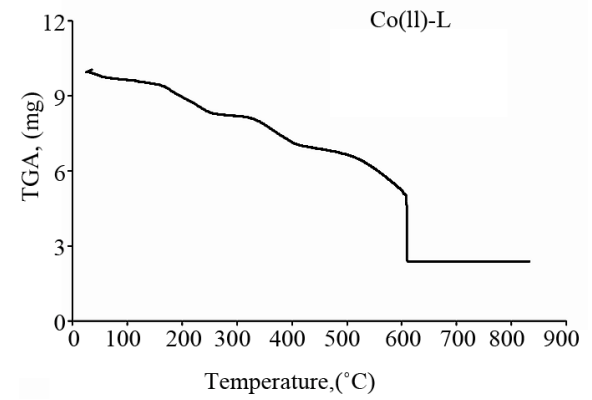

(c)

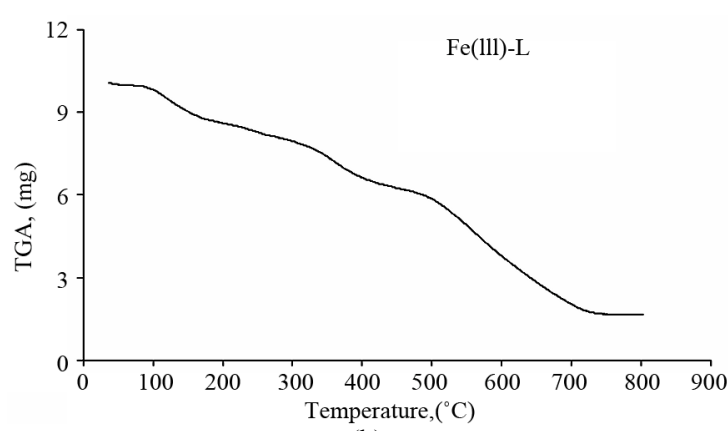

(b)

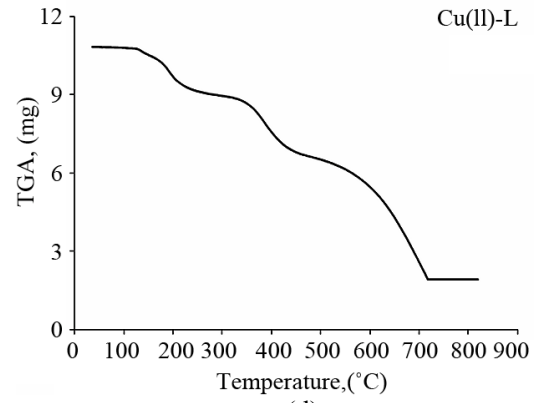

(d)

Figure 3. Thermal analyses of (a) Schiff base ligand (L), (b) Fe(III)-L, (c) Co(II)-L and (d) Cu(II)-L. complexes. 


\subsection{Calculation of Activation Thermodynamic Parameters}

The thermodynamic activation parameters of decomposition processes of the complexes are evaluated graphically by employing the Coats-Redfern relation [30].

$$
\begin{aligned}
& \log \left[\log \left\{\mathrm{W}_{\mathrm{f}} /\left(\mathrm{W}_{\mathrm{f}}-\mathrm{W}\right)\right\} / \mathrm{T}^{2}\right] \\
= & \log \left[\mathrm{AR} / \mathrm{q} \theta \mathrm{E}^{*}\left(1-2 \mathrm{RT} / \mathrm{E}^{*}\right)\right]-\mathrm{E}^{*} / 2.303 \mathrm{RT}
\end{aligned}
$$

where $\mathrm{W}_{\mathrm{f}}$ is the mass loss at the completion of the reaction, $\mathrm{W}$ is the mass loss up to temperature $\mathrm{T}$; $\mathrm{R}$ is the gas constant, $\mathrm{E}^{*}$ is the activation energy in $\mathrm{KJ} / \mathrm{mol}$ and $\theta$ is the heating rate. Since, $1-2 \mathrm{RT} / \mathrm{E}^{*} \cong 1$, a plot of the left hand side of the equation against $1 / \mathrm{T}$ was drawn and the data obtained are given in Table 5. The high values of the activation energies reflect the thermal stability of the complexes. The entropy of activation is found to have negative values in all the complexes which indicate that the decomposition reactions proceed with a lower rate than the normal ones.

\subsection{X-Ray Diffraction}

The trend of the curves decreases from maximum to minimum intensity indicating that all the metal complexes are amorphous in nature in the present metal-ligand formation except the $\mathrm{Cr}(\mathrm{III}), \mathrm{Ni}(\mathrm{II}), \mathrm{Cu}(\mathrm{II})$ and $\mathrm{Zn}(\mathrm{II})$ chelates they have crystalline phase.

\subsection{Structures Interpretation}

On the basis of the above observations, octahedral geometry is suggested for the investigated complexes. The structures of the complexes are shown in Figure 4.

\begin{tabular}{|c|c|c|c|c|c|c|}
\hline Complex & $\begin{array}{l}\text { Decomp. } \\
\text { Temp. }{ }^{\circ} \mathrm{C}\end{array}$ & $\begin{array}{c}\mathrm{A} \\
\mathrm{s}^{-1}\end{array}$ & $\begin{array}{c}\mathrm{E}^{*} \\
\mathrm{~kJ} \cdot \mathrm{mol}^{-1}\end{array}$ & $\begin{array}{c}\Delta \mathrm{S}^{*} \\
\mathrm{~J} \cdot \mathrm{mol}^{-1}\end{array}$ & $\begin{array}{c}\Delta \mathrm{H}^{*} \\
\mathrm{~kJ} \cdot \mathrm{mol}^{-1}\end{array}$ & $\begin{array}{c}\Delta \mathrm{G}^{*} \\
\mathrm{~kJ} \cdot \mathrm{mol}^{-1}\end{array}$ \\
\hline \multirow[t]{5}{*}{$\mathrm{L}$} & $25-140$ & $1.34 \times 10^{5}$ & 72.60 & -33.00 & 72.10 & 80.40 \\
\hline & $140-220$ & $8.53 \times 10^{6}$ & 26.20 & -52.00 & 93.80 & 133.4 \\
\hline & $220-445$ & $7.78 \times 10^{5}$ & 82.20 & -104.0 & 128.8 & 152.0 \\
\hline & $445-630$ & $6.75 \times 10^{10}$ & 95.30 & -141.0 & 191.1 & 212.0 \\
\hline & $630-750$ & $2.91 \times 10^{11}$ & 90.80 & -181.0 & 239.9 & 262.0 \\
\hline \multirow[t]{4}{*}[\mathrm{Fe}(\mathrm{L})\mathrm{Cl}_{2}]{$\mathrm{Cl}$} & $35-185$ & $6.15 \times 10^{4}$ & 43.60 & -46.00 & 72.60 & 90.30 \\
\hline & $185-220$ & $2.69 \times 10^{11}$ & 79.90 & -83.00 & 106.9 & 115.0 \\
\hline & $220-470$ & $1.90 \times 10^{7}$ & 42.00 & -106.0 & 139.1 & 160.0 \\
\hline & $470-775$ & $2.91 \times 10^{6}$ & 82.40 & -146.0 & 177.4 & 202.0 \\
\hline \multirow[t]{5}{*}[\mathrm{Co}(\mathrm{L})\mathrm{Cl}_{2}]{} & $25-160$ & $2.27 \times 10^{9}$ & 141.0 & -46.00 & 63.80 & 82.00 \\
\hline & $160-270$ & $6.28 \times 10^{10}$ & 172.0 & -75.00 & 95.50 & 122.7 \\
\hline & $270-415$ & $2.69 \times 10^{8}$ & 156.0 & -125.0 & 152.6 & 163.4 \\
\hline & $415-650$ & $2.26 \times 10^{8}$ & 114.0 & -191.0 & 210.9 & 266.0 \\
\hline & $650-705$ & $2.09 \times 10^{5}$ & 180.0 & -252.0 & 280.2 & 318.3 \\
\hline \multirow[t]{3}{*}[\mathrm{Cu}(\mathrm{L})\mathrm{Cl}_{2}]{} & $50-245$ & $3.19 \times 10^{9}$ & 68.30 & -59.0 & 82.70 & 106.3 \\
\hline & $245-520$ & $1.31 \times 10^{11}$ & 106.0 & -134.0 & 174.5 & 205.0 \\
\hline & $520-790$ & $1.74 \times 10^{5}$ & 116.0 & -181.0 & 211.0 & 243.0 \\
\hline
\end{tabular}

Table 5. Thermodynamic data of the thermal decomposition of the Schiff base ligand and its metal complexes.

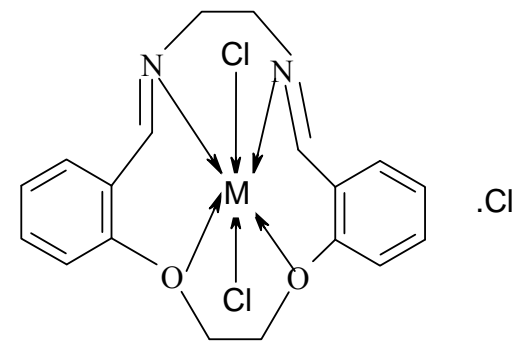

$\mathrm{M}=\mathrm{Ni}(\mathrm{II}), \mathrm{Co}(\mathrm{II}), \mathrm{Cu}(\mathrm{II})$ and $\mathrm{Zn}(\mathrm{II})$.

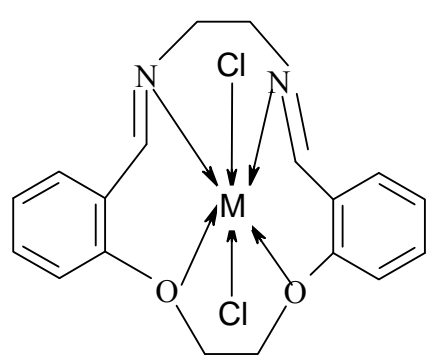

$\mathrm{M}=\mathrm{Cr}(\mathrm{III})$ and $\mathrm{Fe}(\mathrm{III})$.

Figure 4. Structural formula of the metal complexes. 


\subsection{Biological Activity}

The main aim of the production and synthesis of any antimicrobial compound is to inhibit the causal microbe without any side effects on the patients. In addition, it is worthy to stress here on the basic idea of applying any chemotherapeutic agent which depends essentially on the specific control of only one biological function and not multiple ones. The antibacterial activity of the parent Schiff base and its metal complexes against Aspergillus flavus and Canidia albicans fungi and, Staphylococcus $\left(\mathrm{G}^{+}\right)$and E. coli $\left(\mathrm{G}^{-}\right)$bacteria was tested in order to asses their potential antimicrobial agents. The biological activeity of the Schiff base ligand and its metal complexes were also compared with tetracycline (Antibacterial agent) and Amphotericin B (Antifungal agent). The data are listed in Table 6 and Figure 5. According to the data it can be seen that the ligand did not show any biological activity, while all the complexes showed activity against Staphylococcus $\left(\mathrm{G}^{\dagger}\right)$ and E. coli $\left(\mathrm{G}^{-}\right)$bacteria and Canidia albicans fungi. On the other hand, no activity is observed for Aspergillus flavus fungi by the ligand or the complexes [31]. This means that the activity of the newly prepared Schiff base against different microorganisms is enhanced with chelation with different biological active metals.

\section{APPLICATION}

\section{A New Spectrophotometric Determination to $\mathrm{Fe}(\mathrm{III})$ Ions in Natural Water}

The UV-vis spectrum of the Fe(III) solution in the presence of the Schiff base ligand was measured from 250 to $900 \mathrm{~nm}$ at an interval of $1 \mathrm{~nm}$ and an average measuring time of $1 \mathrm{~s}$ per wavelength and the maximum wavelength is found at $313 \mathrm{~nm}$. Several factors influence on the recovery method are studied for [Fe(III)-L] system in order to achieve maximum recovery. The optimum factors are $\mathrm{pH}=3,25^{\circ} \mathrm{C}, 1: 1(\mathrm{M}: \mathrm{L})$ metal to ligand ratio and $30 \mathrm{~min}$. In order to assess the applicability of the proposed method to recover Fe(III) from spiked water samples, the effect of some foreign ions was also investigated. These foreign ions were selected on the basis that they are normally present in natural water samples. Solutions containing various amounts of foreign ions, $\mathrm{Fe}(\mathrm{III})$, and the ligand were subjected to the described spectrophotometric procedure. The tolerable amounts of each ion, given a maximum error up to $1.23 \%$ in the recovery, are summarized in Table 7. As can be seen, all the investigated foreign ions with a relatively high concentration have no adverse effect on the ferric ions determinate.

Recovery tests were carried out on different types of water samples in order to assess its accuracy. The selection of these samples was done in a way to provide a wide variety of sample matrices characterized by different types of interferents. Solutions of water samples containing $\mathrm{Fe}(\mathrm{III})$ with varying a concentration were recovered with the newly Schiff base synthesized under the recommended conditions and the data listed in Table 8 showed satisfactory recovery of $\mathrm{Fe}(\mathrm{III})$. The standard deviation and relative standard deviation of the method were also calculated and their values indicate that, this method has a greater accuracy where the small values for the standard deviation attest to the procedure's fairly high degree of precision. Therefore, the synthesis of these complexes might be established a new line for search to new ligand for determination of ferric ion in natural water.

Table 6. Biological activity of $\mathrm{L}$ and its metal complexes.

\begin{tabular}{|c|c|c|c|c|}
\hline \multirow[b]{2}{*}{ Sample } & \multicolumn{4}{|c|}{ Inhibition Zone Diameter (mm) } \\
\hline & $\begin{array}{c}\text { Escherichia coli } \\
\left(\mathrm{G}^{-}\right) \\
\text {Mean } \pm \text { RSD }\end{array}$ & $\begin{array}{c}\text { Staphylococcus aureus } \\
\left(\mathrm{G}^{+}\right) \\
\text {Mean } \pm \text { RSD }\end{array}$ & $\begin{array}{l}\text { Aspergillus favus } \\
\text { (Fungus) } \\
\text { Mean } \pm \text { RSD }\end{array}$ & $\begin{array}{l}\text { Candida albicans } \\
\text { (Fungus) } \\
\text { Mean } \pm \text { RSD }\end{array}$ \\
\hline Control: DMSO & 0.0 & 0.0 & 0.0 & 0.0 \\
\hline $\begin{array}{c}\text { Tetracycline } \\
\text { (Antibacterial agent) }\end{array}$ & 33 & 30 & ---- & ---- \\
\hline $\begin{array}{l}\text { Amphotericin B } \\
\text { (Antifungal agent) }\end{array}$ & ---- & ---- & 18 & 19 \\
\hline $\mathrm{L}$ & 0.00 & 0.00 & 0.0 & 0.00 \\
\hline$\left[\mathrm{Cr}(\mathrm{L}) \mathrm{Cl}_{2}\right] \mathrm{Cl}$ & $14.33 \pm 0.011$ & $14.43 \pm 0.041$ & 0.0 & $12.433 \pm 0.191$ \\
\hline$\left[\mathrm{Fe}(\mathrm{L}) \mathrm{Cl}_{2}\right] \mathrm{Cl}$ & $13.23 \pm 0.019$ & $13.067 \pm 0.069$ & 0.0 & $11.500 \pm 0.157$ \\
\hline$\left[\mathrm{Ni}(\mathrm{L}) \mathrm{Cl}_{2}\right]$ & $16.40 \pm 0.022$ & $22.333 \pm 0.068$ & 0.0 & $16.000 \pm 0.250$ \\
\hline$\left[\mathrm{Cu}(\mathrm{L}) \mathrm{Cl}_{2}\right]$ & $13.13 \pm 0.012$ & $14.000 \pm 0.143$ & 0.0 & $13.000 \pm 0.428$ \\
\hline$\left[\mathrm{Zn}(\mathrm{L}) \mathrm{Cl}_{2}\right]$ & $20.23 \pm 0.010$ & $25.667 \pm 0.098$ & 0.0 & $12.333 \pm 0.528$ \\
\hline
\end{tabular}






Figure 5. Percent of inhibition zone diameter $(\mathrm{mm})$ relative to used standard vs. the Schiff base ligand (L) and its metal complexes.

Table 7. Effect of some foreign ions on the recovery of $5 \times 10^{-4}$ $\mathrm{mol} \cdot \mathrm{L}^{-1} \mathrm{Fe}(\mathrm{III})$ using $5 \times 10^{-4} \mathrm{~mol} \cdot \mathrm{L}^{-1}$ of L ligand at $\mathrm{pH}=3, \mathrm{t}$ $=30 \mathrm{~min}, \mathrm{~T}=25^{\circ} \mathrm{C}$ and $\lambda_{\max }=313 \mathrm{~nm}$.

\begin{tabular}{ccc}
\hline Foreign Ion Added & [Foreign Ion]/[Fe(III)] & $\mathrm{R}(\%)$ \\
\hline $\mathrm{Ag}(\mathrm{I})$ & 2000 & 98.77 \\
$\mathrm{Cd}(\mathrm{II})$ & 0.200 & 99.45 \\
$\mathrm{NH}(\mathrm{I})$ & 20.00 & 99.62 \\
$\mathrm{Sn}(\mathrm{IV})$ & 2000 & 98.89 \\
$\mathrm{Al}(\mathrm{III})$ & 200.0 & 99.50 \\
$\mathrm{~K}(\mathrm{I})$ & 20.00 & 99.43 \\
$\mathrm{Hg}(\mathrm{I})$ & 20.00 & 99.49 \\
$\mathrm{Ca}(\mathrm{II})$ & 20.00 & 99.47 \\
$\mathrm{Na}(\mathrm{I})$ & 200.0 & 99.50 \\
$\mathrm{Cu}(\mathrm{II})$ & 20.00 & 99.44 \\
$\mathrm{Co}(\mathrm{II})$ & 0.200 & 99.68 \\
$\mathrm{Ni}(\mathrm{II})$ & 20.00 & 99.38 \\
$\mathrm{Zn}(\mathrm{II})$ & 200.0 & 99.50 \\
$\mathrm{Cl}{ }^{-}$ & 200.0 & 99.10 \\
$\mathrm{Mg}(\mathrm{II})$ & 2000 & 99.77 \\
\hline
\end{tabular}

Table 8. Recovery percent (\%) of Fe(III) in spiked natural water samples using $5 \times 10^{-4} \mathrm{~mol} \cdot \mathrm{L}^{-1}$ at $\mathrm{pH}=3, \mathrm{t}=30 \mathrm{~min}, \mathrm{~T}=$ $25^{\circ} \mathrm{C}$ and $\lambda_{\max }=313 \mathrm{~nm}$.

\begin{tabular}{|c|c|c|c|c|c|}
\hline $\begin{array}{c}\text { Water Samples } \\
\text { (location) }\end{array}$ & $\begin{array}{c}\mathrm{Fe}(\mathrm{III})_{\text {spiked }} \\
\left(\mathrm{mg} \cdot \mathrm{L}^{-1}\right)\end{array}$ & $\begin{array}{c}\mathrm{Fe}(\mathrm{III})_{\text {recovered }} \\
\left(\mathrm{mg} \cdot \mathrm{L}^{-1}\right)\end{array}$ & $\begin{array}{c}\text { Recovery } \\
\text { Percent }(\%)\end{array}$ & $\begin{array}{c}\mathrm{SD} \\
\times 10^{-3} \\
\end{array}$ & $\begin{array}{c}\text { RSD } \\
(\%)\end{array}$ \\
\hline \multirow{2}{*}{$\begin{array}{l}\text { Distilled } \\
\text { water }\end{array}$} & 4.65 & 4.641 & 99.81 & \multirow{2}{*}{1} & \multirow{2}{*}{14.14} \\
\hline & 8.42 & 8.409 & 99.87 & & \\
\hline \multirow{2}{*}{$\begin{array}{l}\text { Tap water } \\
\text { (our Lab.) }\end{array}$} & 4.65 & 4.628 & 99.53 & \multirow{2}{*}{1} & \multirow{2}{*}{6.734} \\
\hline & 8.42 & 8.400 & 99.76 & & \\
\hline \multirow{2}{*}{$\begin{array}{l}\text { Nile water } \\
\text { (Egypt) }\end{array}$} & 4.65 & 4.631 & 99.59 & \multirow{2}{*}{4} & \multirow{2}{*}{16.44} \\
\hline & 8.42 & 8.396 & 99.71 & & \\
\hline \multirow{2}{*}{$\begin{array}{c}\text { Sea water } \\
\text { (Gamasah) }\end{array}$} & 4.65 & 4.638 & 99.74 & \multirow{2}{*}{1} & \multirow{2}{*}{10.88} \\
\hline & 8.42 & 8.406 & 99.83 & & \\
\hline \multirow{2}{*}{$\begin{array}{c}\text { Underground } \\
\text { water } \\
\text { (Belqas) }\end{array}$} & 4.65 & 4.629 & 99.55 & \multirow[b]{2}{*}{3} & \multirow[b]{2}{*}{14.89} \\
\hline & 8.42 & 8.403 & 99.80 & & \\
\hline \multirow{2}{*}{$\begin{array}{l}\text { Well water } \\
\left(6^{\text {th }} \text { October }\right. \\
\text { City })\end{array}$} & 4.65 & 4.620 & 99.35 & \multirow[t]{2}{*}{5} & \multirow[t]{2}{*}{18.68} \\
\hline & 8.42 & 8.397 & 99.73 & & \\
\hline
\end{tabular}

$\mathrm{SD}=$ standard deviation and $\mathrm{RSD}=$ relative standard deviation.

\section{CONCLUSION}

Synthesis and characterization of complexes containing $\mathrm{N}_{2} \mathrm{O}_{2}$-donor tetradentate Schiff base ligand have been described in this paper. The spectroscopic data of the complexes give good evidence of proposed structure. The results of the antibacterial screening of the test compounds indicate mild to moderate bactericidal activities and Canidia albicans fungi. Spectrometry procedure used to determine of iron (III) in different types of natural water within recovery test including with stable solution of the newly synthetic Schiff base as selective reagent by highly sensitive, selective and simple method than others.

\section{REFERENCES}

[1] Chen, D. and Martell, A.E. (1987) Dioxygen affinities of synthetic cobalt Schiff base complexes. Inorganic Chemistry, 26, 1026-1987. doi:10.1021/ic00254a013

[2] Collman, J. and Hegedus, L.S. (1980) Principles and application of organotransition metal chemistry. University Science Book, Sausalito.

[3] Zhao, J., Zhao, B., Liu, J., Xu, W. and Wang, Z. (2001) Spectroscopy study on the photochromism of Schiff bases N,N'-bis(salicylidene)-1,2-diaminoethane and N,N'-bis(Salicylidene)-1,6-exanediamine. Spectrochimica Acta Part A: Molecular and Biomolecular Spectroscopy, 57, 149154. doi:10.1016/S1386-1425(00)00353-X

[4] Zgierski, M.Z. and Grabowska, A. (2000) Theoretical approach to photochromism of aromatic Schiff bases: A minimal chromophore salicylidene methylamine. Journal of Chemical Physics, 113, 7845. doi:10.1063/1.1316038

[5] Sawodny, W.J. and Riederer, M. (1977) Addition compounds with polymeric chromium(II)-schiff base complexes. Agnewandate Chemie, 16, 859-860. doi:10.1002/anie.197708591

[6] Panda, B.K. and Chakravorty, A. (2005) Spectroscopic properties of inorganic and organometallic compounds. Journal of Organometallic Chemistry, 690, 3169-3175. doi:10.1016/j.jorganchem.2005.04.012

[7] Krishnapriya, K.R. and Kandaswamy, M. (2005) Coordination properties of a dicompartmental ligand with tetra- and hexadentate coordination sites towards copper(II) and nickel(II) ions Polyhedron. Polyhedron, 24, 113-120. doi:10.1016/j.poly.2004.10.010

[8] Kumar, K.N. and Ramesh, R. (1999) Synthesis of lanthanide(III) complexes of chloro- and bromo-substituted 18-memberedtetraazamacrocycles. Polyhedron, 18, 15611568.

[9] Rekha, S. and Nagasundara, K.R. (2006) Complexes of the Schiff base derived from 4-amino-phenyl benzimidazole and 2,2'-dehydropyrollidene-N-aldehyde with $\mathrm{Zn}$ (II), $\mathrm{Cd}(\mathrm{II})$ and $\mathrm{Hg}(\mathrm{II})$ halides. Indian Journal of Chemistry, 45, 2421-2425.

[10] Cotton, F.A., Wilkinson, G., Murillo, C.A. and Bochmann, M. (1999) Advanced inorganic chemistry. 6th Edition, Wiley, New York. 
[11] Shearer, J.M. and Rokita, S.E. (1999) Diamine preparation for synthesis of a water soluble Ni(II) salen complex. Bioorganic \& Medicinal Chemistry Letters, 9, 501-504. doi:10.1016/S0960-894X(99)00020-7

[12] Singh, K., Barwa, M. S. and Tyagi, P. (2006) Synthesis, characterization and biological studies of $\mathrm{Co}(\mathrm{II}), \mathrm{Ni}(\mathrm{II})$, $\mathrm{Cu}$ (II) and $\mathrm{Zn}$ (II) complexes with bidentate Schiff bases derived by heterocyclic ketone. European Journal of Medicinal Chemistry, 41, 147-153.

doi:10.1016/j.ejmech.2005.06.006

[13] Majumder, A., Rosair, G.M., Mallick, A., Chattopadhyay, N. and Mitra, S. (2006) Synthesis, structures and fluorescence of nickel, zinc and cadmium complexes with the N,N,O-tridentate Schiff base N-2-pyridylmethylidene-2hydroxy-phenylamine. Polyhedron, 25, 1753-1762.

[14] Freiria, A., Bastida, R., Valencia, L., Macias, A. and Lodeiro, C. (2006) Metal complexes with two tri-aza, tri-oxa pendant-armed macrocyclic ligands: Synthesis, characterization, crystal structures and fluorescence studies. Inorganica Chimica Acta, 359, 2383-2394. doi:10.1016/j.ica.2005.12.055

[15] Faniran, J. A., Patel, K. S. and Bailar, J. C. (1974) Infrared spectra of N,N'-bis(salicylidene)-1,1-(dimethyl)ethylenediamine and its metal complexes. Journal of Inorganic and Nuclear Chemistry, 36, 1547-1551. doi:10.1016/0022-1902(74)80621-4

[16] Yano, S., Takizawa, S., Sugita, H., Takahashi, T., Shioi, H., Tsubomura, T. and Yoshikawa, S. (1985) Reactions of metal complexes with carbohydrates: Synthesis and characterization of novel nickel(II) complexes containing glycosylamines derived from a monosaccharide and a diamine. An X-ray crystallographic study of (ethylenediamine) \{N-(2-aminoethyl)-d-fructopyranosylamine $\}$ nic$\operatorname{kel}(\mathrm{II})-\mathrm{Cl}_{2}-\mathrm{CH}_{3} \mathrm{OH}$. Carbohydrate Research, 142, 179-193. doi:10.1016/0008-6215(85)85021-7

[17] Bian, H.D., Xu, J.Y., Gu, W., Yan, S.P., Liao, D.Z., Jiang, Z.H. and Cheng, P. (2003) Synthesis, structure and properties of terephthalate-bridged copper(II) polymeric complex with zigzag chain. Inorganic Chemistry Communications, 6, 573-576.

[18] Mohamed, G.G., Omar, M.M. and Hindy, A.M. (2006) Metal complexes of Schiff basess, preparation, characterization and biological activity. Turkish Journal of Chemistry, 30, 361-382.

[19] El-Ayaan, U., El-Metwally, N.M., Youssef, M.M. and El Bialy, S.A.A. (2007) Perchlorate mixed-ligand copper(II) complexes of $\beta$-diketone and ethylene diamine derivatives: Thermal, spectroscopic and biochemical studies. Spectrochimica Acta Part A: Molecular and Biomolecular Spectroscopy, 68, 1278-1286. doi:10.1016/j.saa.2007.02.011

[20] Surati, K.R. and Thake, B.T. (2010) Synthesis, spectral, crystallography and thermal investigations of novel Schiff base complexes of manganese(III) derived from heterocyclic $\beta$-diketone with aromatic and aliphatic diamine. Spectrochimica Acta A: Molecular and Biomolecular Spectroscopy, 75, 235-242. doi:10.1016/j.saa.2009.10.018

[21] Bharty, M.K., Srivastava, A.K., Dulwere, R., Butcher, R.J. and Singh, N.K. (2011) Synthesis, spectral and X-ray structural studies of $\mathrm{Ni}$ (II) complexes of N'-acylhydrazine carbodithioic acid esters containing ethylenediamine or $o$-phenanthroline as coligands. Polyhedron, 30, 990-996. doi:10.1016/j.poly.2010.12.043

[22] Ghazy, S.E., Kabil, M.A., Shallaby, A.M. and Ammar, N.S. (2001) Flotation-separation of the pollutant species of chromium, cadmium and lead from aqueous solutions and natural waters. Indian Journal of Chemical Technology, 8, 211-218. doi:10.1021/ac00232a002

[23] Leyden, D.E. and Wegschider, W. (1981) Preconcentration for trace element determination in aqueous samples. Analytical Chemistry, 53, 1059-1065.

[24] Zouboulis, A.I., Lazaridis, N.K. and Zamboulis, D. (1994) Powdered activated carbon separation from water by foam floation, Separation Science and Technology, 29, 385-400. doi:10.1080/01496399408002490

[25] Lajunen, L.H.J. (1991) Spectrochemical analysis by atomic absorption and emission. Royal Society of Chemistry, Cambridge.

[26] Vogel, A.I. (1962) Quantitative inorganic analysis includeing elemental instrumental analysis. 2nd Edition, Longmans, London.

[27] Sari, N., Arslan, S., Logoglu, E. and Sakiyan, I. (2003) Antibacterial activities of some amino acid Schiff bases. Journal of Animal Science, 16, 283.

[28] Batley, G.E. and Gardner, D. (1977) Sampling and storage of natural waters for trace metal analysis. Water Research, 11, 745-756. doi:10.1016/0043-1354(77)90042-2

[29] Masoud, M.S., Hindawy, A.M. and Soayed, A.S. (1991) Structural chemistry of some new azo complexes. Transition Metal Chemistry, 16, 372-376. doi:10.1007/BF01024086

[30] Coats, A.W. and Redfern, J.P. (1964) Kinetic parameters from thermogravimetric data. Nature, 201, 68-79. doi: $10.1038 / 201068 \mathrm{a} 0$

[31] Duraiswamy, S, Michael, R.E., Matthias, Z. and Karuppannan, N. (2007) Hydrolytic cleavage of Schiff bases by $\left[\mathrm{RuCl}_{2}(\mathrm{DMSO})_{4}\right]$. Polydedron, 26, 4314-4320. 